\title{
吻合部潰瘍症例の検討
}

\begin{tabular}{lccccr}
\multicolumn{8}{c}{ 東京慈恵会医科大学第 1 外科教室 } \\
小泉 & 裕 & 河井 & 啓三 & 岡部 & 紀正 \\
星 & 康夫 & 足立 & 坦 & 町田 & 崇 \\
綿貫 & 喆 & & & &
\end{tabular}

\section{CLINICAL STUDY ON PATIENTS WITH STOMAL ULCER}

\section{Yutaka KOIZUMI, Keizo KAWAI, Norimasa OKABE, Yasuo HOSHI, Hiroshi ADACHI, Takashi MACHIDA and Tetsu WATANUKI}

The 1st Department of Surgery, Jikei University School of Medicine, Tokyo

吻合部潰瘍42例飞対して, $\mathrm{pH}$ カプセルあるいは有線ガラス電極を用いて胃内 $\mathrm{pH}$ の計測を試及，本症 例の成績ならびに治療法に若干の知見を光た. 42例のうち当科症例は 2 例のみで発生率は $0.4 \%$ 以下であ った。症状は心筒部痛, 下血, 吐血が高頻度に認められ, X線検查, 内視鏡検查でその診断は容易であ る. 本症例の早朝空腹時の胃内 $\mathrm{pH}$ 值は全例 2.0 以下で, basal $\mathrm{pH}$ 値の測定結果が潰癔再発の指標とな りらる.薬物治療に際して，カプセル法により的確な制酸剤の選択が可能であるが，とくに胃粘膜に吸着 性の強いものが著効を示した．手術効果は，胃再切除たけでは不十分で，迷切術を併施する手術法に減酸 効果が上がっていることが認められた.

索引用語 $\mathrm{pH}$ カプセル, basal $\mathrm{pH}$, 胃切後有愁訴患者, 吻合部潰汮, 迷切術.

1.はじめに

従来, 消化性潰瘍の外科療法としては広範囲胃切除術 准一番多く行われてきた。この手術を受けた大多数の患 者はその術後経過をみると概ね良好で满足すべきるので ある.乙かし小数例においては胃切除後障害が発生して いることを絶対に忘れてはならない.最近は，これら手 術に伴ういろいろな障害をできるかぎり防止するために 種々の検討がなされ，迷走神経切断術や小範团贯切除術 か推奖され，それら術式の研究がさかんに行われるよう 飞なってきている，いずれの術式にしてる，消化性潰瘍 の外科療法の目的は，謴㾤を治㾻させるのみならず，そ の潰瘍再発防止にある。乙かし胃切後有愁訴患者のなか 飞，減酸効果が十分兄られず吻合部潰瘍が発生した症例 が少数ながら認められているのが現況である.

教室では胃手術後患者に対しても，図1に示すような 医用 $\mathrm{pH}$ カプセルあるいは有線ガラス電極を用いて胃 内 $\mathrm{pH}$ の計測を行っているが，吻合部潰瘍症例に打け る成績ならびに治療法に若干の知見をえたので報告す
図 1 医用カプセル（上）と有線ガラス電極（下）

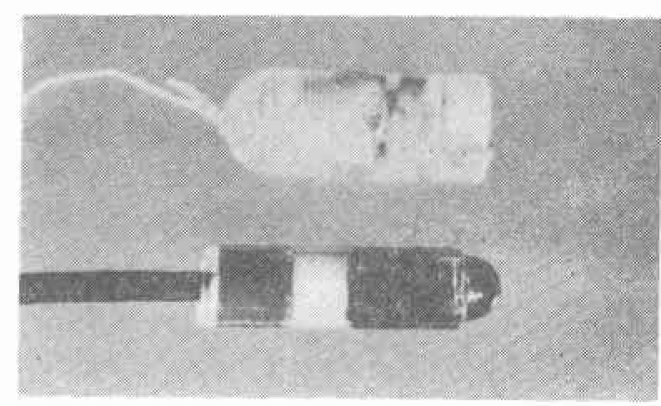

る.

2. 症例について

当科外来ならびに関連病院に愁訴をるって受診した胃 手術後患者300例のらち, 吻合部潰瘍と診断されたのは 42例である.このうち当科技いて初回の胃手術を受け たものは2 例のみである.42例の内訳は, 男性40例, 女 性 2 例, 年齢は 23 歳から 69 歳までで平均年龄は 43 歳であ った. 初回手術後から吻合部潰瘍と猃断されるまで経過 
表 1 教室に拈ける胃分泌機能検査法(カプセル法 あるいは有線法)

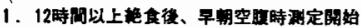

程を合内に固定したあと

2. 安定した桨熊における

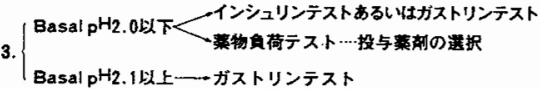

した月数は，最短 2 週間，最長 24 年であり，その平均月 数は 5 年 3 カ月であった。 42 例のらち, 再発再然をくり かえして, 手術(第 2 回目) を施行したものは23例で, これらのらちさらに再手術例（第3回目）は4例であっ た.な撌瘍再発の診断には，表 1 に示す胃分泌機能検 查により, basal $\mathrm{pH}$ の計測を行い, basal $\mathrm{pH} 2.0$ 以下 の症例に対しては潰瘍再発の疑いをるって積極的にX線 検査, 内視鏡検查を行うことにしている.このようにし て吻合部潰瘍の確定診断を下したものは41例で，剖検に より診断されたもの1例である。

\section{3. 症例の分析}

42例の分析を試みると, 表 2 に示すように症状として は, 心窝部痛，下血，堮血の 3 大症状をもって来院して いる，その頻度は，心窩部痛が圧倒的に多く76\%以上市 り，次に下血 $69 \%$ ，吐血 $21 \%$ であった。扗血，下血 はすべて顕性出血である。

表 2 吻合部潰瘍之殓断された症例（第 1 回目 手術後）

\begin{tabular}{|c|c|c|c|}
\hline 坛回数 & 三大状 & 疾 & E対する \\
\hline \multirow[t]{2}{*}{ 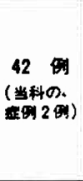 } & 吐血 $(21 \%)$ & 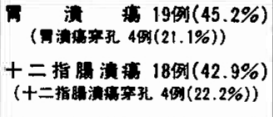 & $\begin{array}{l}\text { 要切除術 } \\
\left\{\begin{array}{l}\text { B. I 伆合 } 16 \text { 例 } \\
(38.1 \%) \\
\text { B. II 伆合 } 25 \text { 例 }\end{array}\right.\end{array}$ \\
\hline & 下血 $(69 \%)$ & 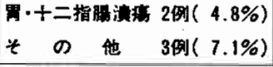 & 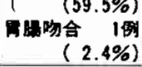 \\
\hline
\end{tabular}

42例の原疾患について検討してみると, 胃潰瘍19例 (45.2\%), 十二指腸潰痬18例 (42.9\%), 胃 -十二指腸潰 掼 2 例 (4.8\%)，その他 3 例（胃炎 2 例，胃下垂 1 例) (7.1\%) である.な打穿孔例は胃潰堭 4 例 (21.1\%)， 十二指腸潰痬 4 例 (22.2\%) 飞認められている.

原疾患に対する手術々式については，胃切除 B. I 吻 合16例 (38.1\%), 胃切除 B. II 吻合25例 (59.5\%) と B. II 吻合の方が多かった。な怙胃腸吻合後に本症が発 生したものが1例㐫った。

吻合部潰瘍の発生部位ならびに深達度を，手術例は切 除標本により，死亡例は剖検により，その他は内視鏡に
空3 胃切後残胃内 basal $\mathrm{pH}$ 值の平均值

（原疾患別と吻合部潰浯について）

\begin{tabular}{|c|c|}
\hline 原 疾 患 & 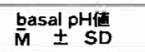 \\
\hline 骨 淟 港 & $4.7 \pm 2.1$ \\
\hline 十二指罴潰癘 & $3.4 \pm 2.2$ \\
\hline 胃 & $5.4 \pm 1.8$ \\
\hline 吻合部謴㾔 & $1.4 \pm 0.3$ \\
\hline
\end{tabular}

より診断した42例50潰瘍について検討してみた。まず潰 瘍発生部位は（1）吻合口部28例 $(56.0 \%)$ ，(2）鞍部 11 例 $(22.0 \%)$ ，（3）輪出脚 9 例 $(18.0 \%)$ ，(4) 輪入 脚 2 例 $(4.0 \%)$ となる. 吻合口部の潰瘍をさらにこま かく検討してみると，吻合口のみ 8 例 $(16.0 \%)$, 吻合 口胃側 3 例 $(6.0 \%)$ ，吻合口十二指腸側 6 例 (12.0\%)， 吻合口空腸側11例 (22.0\%) となり，吻合口空腸側に多 く認められた．潰瘍の深達度を ul 分類で検討すると， ul I はなく, ul II 2 例 $(4.0 \%)$, ul III 32 例 $(64.0$ $\%$, ul IV 16例 (32.0\%) と ul III, IV が95\%以上で 圧倒的に多く認められた。

つぎに，42例の胃内 $\mathrm{pH}$ の面から検討してみた。表 3 に胃切後残胃内 basal $\mathrm{pH}$ 值の平均値を示したもので あるが，吻合部潰瘍は，胃切後にもかかわらず， basal $\mathrm{pH}$ は2.0以下でその平均值は $1.4 \pm 0.3$ 低値を示して いる.

\section{4. 治療}

吻合部潰瘍と診断された場合，直ちに治療を開始する が，その治療法には薬物治療と手術治療がある。

\section{1）薬物治療法}

薬物治療を行ら場合，まず制酸剤を選択するが，この ように残胃を対象とした場合，薬剤の胃からの排出を相 当加味しなけれぱならない，教室では，カプセルあるい は有線ガラス電極を食道内, 残胃内に聥入して各部位の $\mathrm{pH}$ を測定してから薬剤の投与を開始し，その $\mathrm{pH} の$ 変動を実際に記録している。薬物治療を試み，きわめて 効果の認められた症例を示したものが図2の症例であ る. 吻合部潰瘍 (A) は，30歳女性で，胃潰煌（多発 性)で胃切除 (B. I 吻合術)を受け，1年後胸やけ, 心窝部痛, 背部痛の愁訴をもって来院, 直ちに胃 $\mathrm{x}-\mathrm{p}$, 内視鏡検查を施行し吻合部潰瘍と診断された症例であ る.この症例にカプセル検查を施行して食道, 残胃内 $\mathrm{pH}$ を測定してみると，下部食道内 $\mathrm{pH}$ は3.0から5.5と $\mathrm{pH}$ の動摇が認められ，さらに残胃内 $\mathrm{pH}$ も 1.5 から4.6 と $\mathrm{pH}$ の動摇があるが，最低 $\mathrm{pH}$ は1.5を示していた。 
図 2 吻合部潰瘍の薬物治療の実際（カプセル法に よる制酸効果の判定)

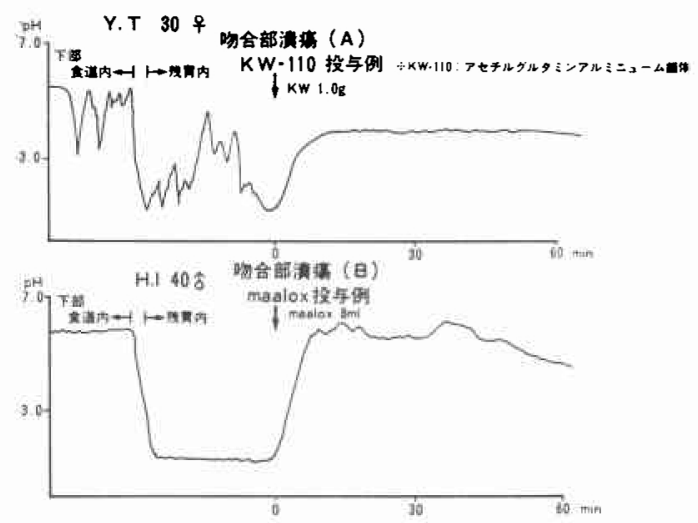

これは胃液や腸液の食道内や残胃内の逆流を示唆する pH 曲線を示し，そのため愁訴が強くなったと思われ る. 本症例に KW-110 (アセチルグルタミンアルミニュ 么錯体） $1.0 \mathrm{~g}$ を微温晹 $30 \mathrm{ml}$ にとかし服用させると， $\mathrm{pH}$ 曲線は 5 分から 7 分で上昇傾向を示しはじめ，10分 で完全に $\mathrm{pH}$ 4.0レベルで安定し, plateau 時間が長く 続きその制酸持続時間は60分以上にわたっている。この 症例は 3 力月間 KW-110 の投与と食事療法を行い潰瘍 の消失が認められ, 愁訴は全くなくなって社会復州して いる.

つぎに, 吻合部潰癔症例（B）（図 2 ）は，40歳男珄 で十二指腸蛽瘍の診断のもとに胃切除 (B. I 吻合術) を受け 3 年後，心窩部痛，吐血，下血を愁訴として来 院, 諸検査で吻合部潰瘍と診断された症例である.カプ セルの $\mathrm{pH}$ 曲線は，下部食道内で $\mathrm{pH} 5.8$ を示し安定 し, 残胃内 $\mathrm{pH}$ は1.2 と高酸を示し各部位の $\mathrm{pH}$ の動 摇は認められず安定した $\mathrm{pH}$ 曲線を示している。この 症例に Maalox $8 \mathrm{ml}$ を投与した $\mathrm{pH}$ 曲線は図 2 の通り である. Maalox 投与後まむなく, pH 6.0 レベルに急 上昇し，その制酸効果時間む60分以上に及んでいる。 の症例は直らに入院, 輸血を施行し, Maalox, 牛乳療法 を 4 力月間行い, 潰癔は洀痕治瘾し, 現在も再発, 再燃 が認められていない。これらの症例のように, 実際に食 道, 残胃内 $\mathrm{pH}$ 曲線の分析をし, 薬剤の投与を試み, 患者の愁訴にあった薬凨を選択し, 潰瘍の治療方針を決 定している。

残胃を対象とした場合，とくに胃内容の排出が早いた め，胃粘膜に吸着性の強い薬剤が有効であると思われ る. 現在, 長期に follow-up 出来ている症例は 8 例であ
るが，再発，再然は防止できている。

2）乎術治療法

薬物治療法にも限度があり, 再発, 再然をくりかえ し，手術療法（第 2 回目手術）にふみきらざるをえなか った症例は23例であった。これら23例の内さらに再々発 をおこし，手術（第 3 回目手術）を施行したものか 4 例 あり，手術療法を施行した合計27例について検討を加壳 た。第 2 回目手術例23例の 術式の内訳は，胃切除 1 例 (初回手術は胃腸吻合)，胃再切除 17例（B. II 吻合14 例, R - Y 吻合 3 例)，S. V+胃再切除 3 例，S. V, T. V 単独各 1 例であった。

第 2 回日手術後に長期に follow-up 出来た12例を表 4 に示す．測定できた症例の術前の basal $\mathrm{pH}$ は全例2.0 以下であった.NO. 5，6，7の3 例は現在のところ潰湯 の再発は認められないが, 術後の basal pH はいぜんと して2.0以下を示し厳重な経過観察を行っている症例で 西る。 NO. 9，10，11，12の4 例は，心窩部痛，下血， 此血をくりかえし，再発が確認され（表 4),第3回目手 術にふみきらざるをえなかったもので表 5 に示す。これ ら吻合部潰瘍再手術例（第 3 回目）の術式は，胃再々切

表4 長期に Follow up できた吻合部潰瘍（第 2 回目）于術症例

\begin{tabular}{|c|c|c|c|c|c|c|c|}
\hline 症 例 & गे & 性 & 主 訴 & 手行々式 & \begin{tabular}{|l|} 
和前 \\
Basalph
\end{tabular} & \begin{tabular}{|l|} 
Basalntat \\
Basal
\end{tabular} & 俑 考 \\
\hline 1 & 38 & $\mathbf{F}$ & 血 & 罱切 除(B & 1.9 & 2.4 & 释過艮 \\
\hline D. & 51 & $M$ & $\begin{array}{l}\text { 心管部痛 } \\
\text { 地 }\end{array}$ & S.V+䏣再 & 1.3 & $2.8 \leftrightarrow 5.5$ & 経過夏妵 \\
\hline b. & 2 & $M$ & $\begin{array}{l}\text { 心窝部㾝 } \\
\text { 盄 }\end{array}$ & $v$ & 1.5 & 6.3 & 経访 \\
\hline 0.4 & & $\mathrm{~F}$ & 心篅部㴖 & $S . V+T$ & & & \\
\hline NO. 5 & 56 & M & 血 & 骮再 & 不明 & .2 & 経迥 \\
\hline NO. 6 & & M & T & $S . V+R$ & & & 怪进 \\
\hline NO. 7 & 3 & M & & V & & & 経退 \\
\hline NO. 8 & 62 & $M$ & 心昂部呞 & 用再切琛(B & & & 释過良好 \\
\hline NO. 9 & 3 & $M$ & 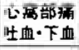 & (再切除(B. III) & & 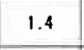 & 再 \\
\hline 80.10 & 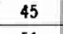 & in & 心窝部期 & & & & 7 \\
\hline NO.11 & 51 & $\mathrm{M}$ & 下 & & & & 再 \\
\hline No.12 & 27 & $M$ & 下血·吐血 & 国再切除(B. II) & 不明 & 1.3 & 発 \\
\hline
\end{tabular}

表 5 吻合部潰場（第 3 回目）再手術症例

\begin{tabular}{|c|c|c|c|c|c|c|c|}
\hline 鉦的 & 年令 & 任 & 主 部 & 手街々式 & $\begin{array}{l}\text { 䚘新 } \\
\text { BasalpH }\end{array}$ & Basalph & 倮 考 \\
\hline No.9 & 37 & M & $\begin{array}{l}\text { 下血 } \\
\text { 吐血 }\end{array}$ & 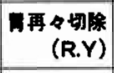 & 1.4 & 不明 & $\begin{array}{l}\text { Follow up } \\
\text { 出来ず }\end{array}$ \\
\hline No.10 & 45 & M & 心部事 & 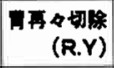 & 1.4 & 不明 & 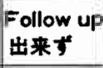 \\
\hline NO.11 & 51 & M & 下血 & $\begin{array}{r}\text { 再再々切除 } \\
\text { (R.Y) }\end{array}$ & 1.1 & 1.1 & 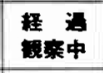 \\
\hline NO. 12 & 27 & M & $\begin{array}{l}\text { T血 } \\
\text { 昍血 }\end{array}$ & 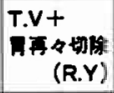 & 1.3 & 6.8 & $\begin{array}{l}\text { 玨逜 } \\
\text { 良好 }\end{array}$ \\
\hline
\end{tabular}


表 6 吻合部潰瑒に対する術式別減酸効果の判定

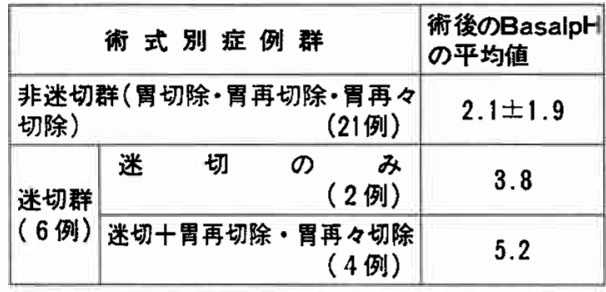

稌 3 例 (R. Y 吻合)，T.V+胃再々切除 (R. Y 吻合) 1 例であった。 follow-up 出来た 2 例のうち NO. 11

（表 5 ）は，術前術後の basal pH は1.1と全く減酸効 果は上がっていず，いぜんとして㷃重な経過観察か必要 である症例で, NO. 12 は術後の basal $\mathrm{pH}$ は6.8を示 し，完全な無酸レベルになっていて経過良好で，再々発 は認められていない。

われわれの経験した吻合部潰癔にたいする手術（第 2 回目，第3 回目）27例の術式別減酸効果は表 6 に示すご とく, 非迷切群 (胃切除, 胃再切除, 胃再々切除) 21 例, 迷切群 (迷切単独 2 例, 迷切十胃再切除・胃再々切 除 4 例） 6 例であった. 各術式の術後 basal pH を測定 して平均值を検討した結果，非迷切群は2.1土1.9であ り, 迷切群の迷切単独では3.8, 迷切十胃再切除・胃再 々切除では5.2 と明らかに有意の差で迷切群に減酸効果 が上がっていることが認められる。

吻合部潰浧に対しては，早晚手術治療が必要と思われ るが，第 2 回目，第 3 回目手術例にみられたように，胃 再切除・胃再々切除のみでは再々発の危険性が認められ るため，その際の手術術式は，われわれの 経験による と, 迷切を加えた症例の方がより完全な減酸効果がえら れ，潰瘍の再発，再々発㤃止出来るように思われる。

\section{5. 考 察}

広義の吻合部潰瘍は，胃または十二指腸疾患の手術療 法の際に行われる吻合術後に発生する潰痬を全部含めた ものをいい, 術後消化性潰瘍, 吻合辺縁潰痬, 二次的潰 瘍なども同義語で使われている。これらの謴瘳発生部位 は吻合口の辺縁で空腸側に圧倒的に多いたふ，吻合部潰 瘍 (Stomal ulcer) という疾患名で呼ばれることが多 い，著者らは，吻合部潰瘍42例をもとにして，本疾患に 関寸る諸問題に検討を加光た。

まず発生頻度からみると，本邦では，一般に発生頻度 はそれ程高くないといわれているが，初回手術例を術後 完全に follow-up することは困難であるので，実際には
報告された頻度より少し多いのではないかと思われる。 著者らが取りあつかった吻合部潰瘍42例のうち40例は初 回手術を他施設で受けたものである．当科で初回手術を 受计たものは 2 例で, 当科での発生率は, 全消化性潰瘍 手術例の $0.4 \%$ 以下にすぎない，諸家の報告であ本邦は $1.0 \%$ 以下と報告があり ${ }^{1)}$ ，著者らの施設と差異はない よらに思われる。

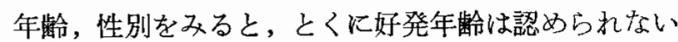
が，平均年㱓は42筬であった。このことは患者の社会的 地位など重要な年代で, 精神的, 肉体的にも負担の多い 年齢に多い上らに思われる。性差は圧倒的に男性に多 く，95\%以上に認められている.

症状としては, 心窩部痛, 吐血, 下血の 3 大症状か圧 倒的に多く，その頻度は心窝部痛は全症例の76\%，下血 は69\%，吐血は21\%に認められた。しかし他の症状は全 くなく，いきなり下血，昍血を主訴として来院したもの が $24 \%$ あり，他疾患と鑑別診断を要する意味で注意しな ければならない。しかも一般に心窩部痛の程度は強く， 初回手術前の心窝部痛の程度と全く一致している症例が 多いことは興味深いことであった. 上記の症状を胃切後 主訴として来院した患者に対して, 直ちにX線検查, 内 視鏡検査によって，容易に診断は可能となっているのが 現況である。著者らは早期空腹時に胃切後有愁訴患者の 胃内 $\mathrm{pH}$ の測定により basal $\mathrm{pH}$ の計測を行った。そ の結果によると，吻合部潰瘍症例全例に扎いて basal

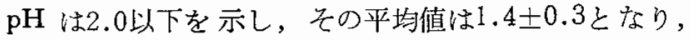
健常人の平均値 $1.7 \pm 0.2$ に比して, きわめて異常な低值 を示していることが分かった。いずれの文献をみてる攻 撃因子として, 胃酸の役割を重視しているが, 胃切後患 者の basal $\mathrm{pH} 2.0$ 以下の症例では現在潰瘍再発は認め られなくとも, 将来吻合部潰瘍の発生がきわめて高い” ことから, pH 2.0 を“danger point”として胃内 $\mathrm{pH}$ 值を指標としている，著者らは，胃切後患者に対して術 直後から, 長期に $\mathrm{pH}$ の変動を記録し $\mathrm{pH}$ の低值を示 寸症例には積極的にX線検査, 内視鏡検査, 血中ガス卜 リン值の測定を行い早期に潰瘍再発の予防，発見につと めることが肝要であると考えている。

本症と診断されるまでに経過した平均月数は 5 年 3 力 月であり, 最短 2 週間, 最長 24 年であっだ。したがって 術後 5 年前後が二番多く注意する期間と思われる. 諸家 の報告のうち Young ${ }^{3\}}$ らの報告とほぼ一致している.

原疾患を検討してみると，42例のらら胃潰瘍19例 (45.2\%)，十二指腸潰瘍18例 (42.9\%) と胃潰痬と十 
二指腸潰瘍の羑は認められていない，諸家の報告では， 十二指腸潰演に多く認められている4 点で, 異った結果 がえられた。ささら胃潰痬, 十二指腸潰瘍の网群とも穿 孔を合併していたものが $20 \%$ 以上占めており, 穿孔例に 発生率が高いことは今後その原因を検討する必要がある 5 .

潰瑒再発部位を検討してみると，吻合口部に $56 \%$ ，空 腸部 (鞍部, 輸入脚, 輸出脚を含めて) は44\%となり, Wychulis の $81 \%$ は空腸に認められた報告と異る結果で あった．しかし著者らが，吻合口部を細分類した結果に よると，吻合口部から空晹側代か汁ての発生率が $22 \%$ 認 められこれらを合計すると，吻合口ふら空腸側の潰瘍の 発生は66\%となり，諸家の報告とほぼ同じ傾向が認めら れた。これらの原因は, 胃液 (高酸の) が粘膜抵抗の少 ない空腸に直接接するためと考兄られる.とくに R.Y 吻合術の際汇は, 胃空腸吻合口部に胆汁等のアルカリ性 の腸液の混入があまりないために空腸側に實啺の発生が 多い傾向が認められている。な拉空腸部のうち輸入脚部 の発生は $4 \%$ と非常に少なく, 輸入脚, 輸出脚の同時に 発生したものは1例だけ認められたにすぎなかった。

本症と診断された場合に，内科的治療法にするか，外 科的治療法にするかという問題については，大部分は内 科的治療で治瘾する など合併症のある場合は別として，患者自身 2 度目の手 術となるとかなり抵抗を示するのが多く，このことから も,まずは内科的治療法より始めるのが妥当ではないか と考えられる。

著者らは, 薬物治療を開始するのに，まず早朝空腹時 カプセルを嚥下させ，食道，残胃内 $\mathrm{pH}$ 曲線の分析を 行い，患者の愁訴にあった薬剤を選択してきめのこまか い治療法を行っているが，効果をあげた症例が認められ ている.残胃を対象とした薬剤としては胃からの排出を 十分考えに入れて投与しなければならない。著者らが武 みた薬剤では，KW-110 (アセチルグルタミンアルミニ ニム錯体)など in vitro では弱い制酸作用が認められ たにすぎないか，実際に患者に投与した in vivoの成 績からみると, $\mathrm{pH} 4.0$ レペルで plateau 時間が 1 時間 以上も続き，予想をはるかにこえた制酸効果が認められ たとの報告的のと拈り，吻合部潰瘍例にも好成績が認め られた，KW-110のこのような作用は，田中 ${ }^{7)}$ ，矢野 $ら^{8)}$ は胃運動を抑制し微弱な制酸力を持続させ攻撃因子 を緩和させる作用があるのではないかと述べている。

Laalox 投与も試みたが，投与後 $\mathrm{pH}$ の上昇梳，急速
に $\mathrm{pH} 6.0$ レベルを維持出来，その制酸時間も，約40分 から60分以上にわたり，十分な制酸効果が認められ，再 発潰瘍に良好な成績をおさめた。この事実は，Maalox 等の胃粘膜に吸着性の強い薬剂が効果を現わすことを示 している. 現在, 長期間 follow-up できている症例は8 例あるが，再発再燃は認められていない，また内科的治 療法により再発は防止されているが，胃内 $\mathrm{pH}$ の上昇 は全く期待できなかった。

本症に対する内科的治療にる限度があり，再発再燃す るものが多く，早晚手術治療涾みきらざるをえなかっ た症例は 42 例のうち23例であった。この 23 例のうち 5 例 は, 穿孔, 大出血等の合併症により直ちに手術を施行し たもので，他の18例は内科的治療の経過をみながら手術 を施行したものである.

手術治療（第 2 回目）の後, 再び再発をくりか学し て, 再手術（第 3 回目）を施行した症例は 4 例認められ た.これらの手術時の所見ならびに他疾患で死亡した剖 検例を加えた28例について, 胃切後潰瑒再発の要因を手 術術式の問題を含めて検討を加えた.

一般に消化性潰瘍の原因にはいろいろの説があり，定 説をみないが，吻合部潰瘍発生の要因についてはいくつ かあげることがでさる。

Streicher" らは次のものを要因としてあげている.

1）ガストリン産生粘膜が残存するとき，2）残胃が大 きすぎるとき．3）吻合部をでの空腸係蹄が長すぎると き４）空腸輸入脚が胃大弯側沟合されるとき５） 吻合した小腸係踣が捻れたり，結腸間膜裂吵で絞められ たとき．6）胃切除断端が広く横向きに小腸が吻合され たとき７）吻合部内躻に不適当な縫合材料の露出をみ るとき.8) 勝島に腺腫のあるとき (Zollinger-Ellison 症候群).9）上皮小体に腺腫のあるとき. 以上の9項 目があげられているが，著者らの検討では28例中 1 例 は，胃腸吻合術など明らかに手術法そのるのの愦りがあ り，17例では，残胃が大きいことが忍められている。こ れら17例のらちには, 縫合綟系の残存によるるのが 1 例 ある. そのほかの10例は残胃はきわめて小さく理想的で 消化性潰瘍の外科的治療法の原則を守って施行されてい るにもかかわらず，潰瘍再発をくりかえしていた症例が あった。

一般に潰澨が再発した症例では, 初回消化性潰瘍手術 後の再発に比して, 再々発率が高いとの報告 ${ }^{103}$ があり， 著者らの検討した23例のうち 4 例再々発が認められ， これらの症例では，残胃は潘とんど残っていず，きわめ 
て小胃にもかかわらずいぜんとして，胃内 $\mathrm{pH}$ は2.0以 下を示し著明な胃分泌の充進が認められている。これ らの症例に対して, 血中の gastrin 值を調べた結果, gastrin 值は，むしろ正常ないし低値を示していた．胃 分泌の克進の原因としては，胃壁細胞自体にも著明な過 形成があり，正常胃の 6 倍, 胃・十二指腸潰瘍の 3 倍も

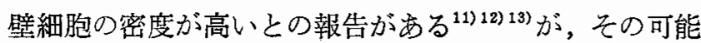
性る考觉られている，その他の要因としてあげられてい る，Z-E 症候群，上皮小体腺腫等は 1 例む認められて いない。このような要因の分析からみて, 吻合部潰瘍に 対する手術術式は，残胃の大きいむのには胃再切除で十 分と思われるが，長期に follow-up した結果をみると， 非迷切群（胃切除, 胃再切除, 胃再々切除) の basal $\mathrm{pH}$ の平均值は $2.1 \pm 1.9$, 迷切群のうち, 迷切のみでは 3.8 , 迷切十胃再切除・胃再々切除では5.2と明らかな有 意の差で, 迷切群に減酸効果が上がっていることが認め られた。この事実は，潰瘍発生に関する塩酸分泌の意 義，塩酸分泌汶対する迷走神経の占める比重により，迷 切を併施する方がより効果的であるう。教室では，十二 指腸潰瘍症例飞は積極的に迷切術を施行しているが，そ の際, 胃切開しないで有線ガラス電極を胃内に挿入し， 術中小弯側 3 点, 大弯侧 3 点の 各部位の 胃粘膜上 $\mathrm{pH}$ の測定をしている.この方法により迷切完了時各部位の 胃内 $\mathrm{pH}$ の上昇を確認し，迷切効果の完全性を検討中 であるが，これら吻合部潰瘍症例の迷切時もこれらの完 全性の問題を含めて，今後それら諸問題の解決に検討を 要すると考光ている。

\section{6. 結 語}

1） 42例の吻合部潰瘍のうち40例は他施設で初回手術 を受けたもので，当外科の手術例は 2 例で 発生率は0.4 \%以下である。㐬た性別では男性に压倒的に多かった。

2）症状は， 3 大症状の心䈪部痛，下血，吐血が認め られ，胃切後にこれらの主訴をむって来陸した患者に は, 積極的に胃内 $\mathrm{pH}$ の測定 (basal pH), X線検査, 内視鏡検查を施行すべきで岁る。

3）本症患者の胃内 $\mathrm{pH}$ の計測の絬果，全例 basal $\mathrm{pH}$ は2.0以下を示し，その平均値は1.4 10.3 となり, 健常人の平均値 $1.7 \pm 0.2$ に比して, き和めて低值を示し ていた.

4）術直後より，胃内 $\mathrm{pH}$ の計測をくりか兄し，術後 6 カ月をすぎても $\mathrm{pH}$ の上昇傾向が認められず， basal $\mathrm{pH}$ はいぜんとして2.0以下を示す場合は，本症発生の 危険率が 高いので, basal $\mathrm{pH}$ の計測結果が 溃瘍雪発の
指標となりらる。

5）本症と診断された場合，まず内科的治療を試及る が, その際カプセルを嚥下させ, 食道, 残胃内 $\mathrm{pH}$ 曲線の 分析を試み，その患者の愁訴に適合した薬剤を in vivo で投与し，その制酸効果時間の測定により薬剤の選択が 可能であった.

6）薬剤は，残胃からの排出を加味しなければなら， ず, KW-110, Maalox, milk 等胃粘膜に吸着性の強いも のが著効を示すが， basal $\mathrm{pH}$ の上昇は全く期待出来ず， 早晚手術療法にふみきらざるをえなかった症例は23例市 り,この内 4 例は再々発症例であった。

7） 23 例の手術例（第 2 回目），4例の再手術（第 3 回 日)の合計27例の手術例を検討した結果，これら術後の， 減酸効果をみると迷切群は非迷切群に比して有意の差で 滅酸効果が上がっていたことが認められた。

8）迷切については, 迷切術の際, 術中から術後にか けて, 胃粘膜上 $\mathrm{pH}$ の測定を行らことは, 迷切術の完 全性を確かめるのにきわめて有用な検梪法と考元てい る.

\section{文 献}

1) 大井 実：胃演瘍症. 南汇堂, 東京, 1957.

2）綿貫 䔩伍か：食道・胃の $\mathrm{pH}$ 測定法と艺の意 義, 今日の消化器病の䛦断と治療, 近藤台五郎・ 竹本忠良編，医学図畫，329-338，1972.

3) Young, G.A., et al.: Surgical treatment of gastrojejunal stomal ulcer. Amer. J. Surg., 104: $231-237,1962$.

4) 大井 実: 吻合部溃瘍. 臨床外科全書 4 巻(1): 249-258，金原出版，東京， 1968 。

5) Balsam, T., Calem, W.S. and Langsam, A.A.= Marginal ulcer after subtotal gastrectomyA medical or surgical problem. J.A.M.A., 185: 704-705, 1963.

6) 河井啓三注か：Nーアセチルグルタミンアルミニ ウム錯体 $(\mathrm{KW} 110)$ 投与時のカプセル法によ る胃内 $\mathrm{pH}$ ○研究. 臨床と研究, $51: 1707-$ 1713,1974 .

7) 田中 洪泳か : N-acetyl-L-glutamine alumineum complex (KW-110) の抗溃㻛作用およびそ の他の薬理作用。日薬理誌, 68:602-617, 19 72 .

8) Yano, S. et al.: Inhibitory effect of $\mathrm{N}$-acetylL-glutamine alumineum complex (KW-110) and related compounds gastric ernosion and mobility in stressed animal, 応用薬理, 1: 16, 1974.

9) Streicher, H.J. and Schlosser, V.: Das Rezidivulcus nach Magenresektion: Beitrag 
zur Ursache, Diagnose und Therapie, Der Chirurg, 37: 343-349, 1966.

10) Thompson, J.E. and Dailey, T.H.: Recurrent ulceration after operation for peptic ulcer: Results after gastrectomy and vagotomy in 64 cases. Ann. Surg., I63: 704-712, 1966.

11) Freisen, S.R., Tracy, H.J. and Gregory, R.A.: Mechanism of the gastric hypersecretion in the Zollinger-Ellison syndrome: Successful extraction of Gastrin-like activity from metastases and primary pancreaticoduodenal islet cell carcinoma. Ann. Surg., 155: 167-174,
1962.

12) Polacek, M.A. and Ellison, E.H.: A comparative study of parietal cell mass and distribution in normal stomachs, in stomachs with duodenal ulcer, and in stomachs of patients with pancreatic adenoma. Surg. Forum., I4: 313-315, 1963.

13) Polacek, M.A. and Ellison, E.H.: Parietal cell mass and gastric acid secretion in the Zollinger-Ellison Syndrome. Surgery, 60: 606614, 1966. 